\title{
Straddling two continents and beyond three worlds? \\ The case of Turkey's welfare regime
}

\author{
Martin Powell and Erdem Yörük
}

\begin{abstract}
This article aims to consider how Turkey has been classified in the welfare regime literature, and on what basis it has been classified. This will then form the basis for exploring whether there appears to be any variation between approaches and methods and/or between the "position" (e.g., location or language) of the authors. Studies of Turkey's welfare regime exhibit a significant degree of variation in terms of both approaches and conclusions, resulting in little in the way of consensus. Among Turkish-language studies (and some, but not all, Turkish scholars writing in English), there does seem to be a broad consensus that Turkey may be classified as part of the Southern European welfare model, which squares with the modal conclusion of the English-language studies on the topic. However, some "regional" studies conclude that Turkey is part of the Middle East and North Africa (MENA) region, while many of the cluster analyses suggest a wide variety of clusters that are not geographically contiguous.
\end{abstract}

Keywords: Welfare regimes; Turkey; Esping-Andersen; social policy; welfare state; Western lens

\section{Introduction}

There have been extensive debates on Gøsta Esping-Andersen's classic text The Three Worlds of Welfare Capitalism, ${ }^{1}$ which is arguably the most cited work in social policy. Much of this debate, however, focuses on his original "three worlds," which comprises 18 nations. There has been some material

\footnotetext{
Martin Powell, School of Social Policy, Health Services Management Centre, University of Birmingham, B15 2RT, Edgbaston, Birmingham, United Kingdom, m.powell@bham.ac.uk.

Erdem Yörük, Department of Sociology, Koç University, 34450, Sarıyer, Istanbul, Turkey and Department of Social Policy and Intervention, University of Oxford, UK, eryoruk@ku.edu.tr.

1 Gøsta Esping-Andersen, The Three Worlds of Welfare Capitalism (Princeton, NJ: Princeton University Press, 1990).
} 
adding an extra "world" (e.g., "Southern European") or a few nations at the margins, but much less focus on moving beyond the original "three worlds" to explore those nations that actually contain the vast majority of the world's population. While a number of scholars have explored broadening theories of Western welfare states and analyses of Esping-Andersen's "three worlds" so as to encompass other nations as well, ${ }^{2}$ it remains unclear if the original concepts and measures that were designed (largely) for Western Europe are appropriate for other worlds.

In this article, we explore these issues by presenting a meta-analysis of the scholarly works that have classified the Turkish welfare regime as part of existing welfare regime clusters. We have chosen to focus on the case of Turkey because it differs in a number of ways from Esping-Andersen's original 18 nations. First, it is a middle- rather than a high-income country. Second, Turkey's historical and geographical position within the Middle East has largely shaped its welfare regime, with the population being predominantly Muslim and the Islamic tradition of charity being deeply entangled in the modern Turkish welfare system. ${ }^{3}$ At the same time, Turkey is also a member of the Organisation for Economic Co-operation and Development (OECD) and was accepted as an official European Union (EU) candidate in 1999, which was followed by the opening of accession negotiations in $2005 .{ }^{4}$ Moreover, scholars appear to be uncertain about the Turkish welfare regime, as they have produced a wide and rather confusing variety of different terms and classifications,

2 lan Gough, "East Asia: The Limits of Productivist Regimes," in Insecurity and Welfare Regimes in Asia, Africa, and Latin America: Social Policy in Development Contexts, ed. Geoffrey D. Wood et al. (Cambridge: Cambridge University Press, 2004): 169-201; Jeremy Seekings, "Prospects for Basic Income in Developing Countries: A Comparative Analysis of Welfare Regimes in the South" (University of Cape Town, 2005), http://open.uct.ac.za/handle/11427/19413; Geof Wood and lan Gough, "A Comparative Welfare Regime Approach to Global Social Policy," World Development 34, no. 10 (2006): 1696-1712; Nita Rudra, "Welfare States in Developing Countries: Unique or Universal?," Journal of Politics 69, no. 2 (May 1, 2007): 378-396; lan Gough, "European Welfare States: Explanations and Lessons for Developing Countries," in Inclusive States: Social Policy and Structural Inequalities, ed. Anis Ahmad Dani and Harjan de Haan (Washington, DC: World Bank Publications, 2008): 39-72; Mine Eder, "Retreating State? Political Economy of Welfare Regime Change in Turkey," Middle East Law and Governance 2, no. 2 (2010): 152-184; Massoud Karshenas and Valentine M. Moghadam, "Bringing Social Policy Back in: A Look at the Middle East and North Africa," International Journal of Social Welfare 18, no. s1 (2009): 52-61; lan Gough and Göran Therborn, "The Global Future of Welfare States," in The Oxford Handbook of the Welfare State, ed. Francis G. Castles, Stephan Leibfried, Jane Lewis, Herbert Obinger, and Christopher Pierson (Oxford: Oxford University Press, 2010): 741-758; Miriam Abu Sharkh and lan Gough, "Global Welfare Regimes: A Cluster Analysis," Global Social Policy 10, no. 1 (April 1, 2010): 27-58; lan Gough and Miriam Abu Sharkh, "Financing Welfare Regimes: Mapping Heterogeneous Revenue Structures," International Journal of Social Welfare 20, no. 3 (2011): 280-291.

3 Ayse Idil Aybars and Dimitris Tsarouhas, "Straddling Two Continents: Social Policy and Welfare Politics in Turkey," Social Policy \& Administration 44, no. 6 (2010): 746-763.

4 Ibid. 
such as "eclectic social security regime," "successful informal security regime,"6 z "Southern European or Mediterranean,"7 "inegalitarian corporatist,"8 "minimalist welfare state," "residual,"10 "productive plus" regime, ${ }^{11}$ and "egalitarian corporatist system." 12

This article aims to consider on what basis Turkey's welfare regime has been classified in the existing literature by conducting a structured literature search within the Scopus database. This search will then form the basis for exploring whether there appears to be any variation between approaches and methods and among the "position" of the authors (in terms of, e.g., location or language). For example, are there differences between the conclusions of Turkish and nonTurkish scholars, or between studies written in the English or Turkish languages? We demonstrate that there is an extensive and growing literature on the Turkish welfare regime. The "three worlds" literature continues to expand, a trend that is apparently reflected in the number of studies analyzing the Turkish case. This study will specifically examine the literature on Turkey's welfare regime in order to help researchers critically evaluate the existing scholarship and locate their prospective work both within and beyond the existing literature. By comparing the Turkish- and English-language literature, as well as large- $\mathrm{N}$, regional, and single-country studies, it will aid in understanding the epistemological taxonomies that underlie welfare regime classification. The main contribution of the study is that it will help students of the Turkish welfare regime observe the dominant tendencies or paradigms that shape the welfare regime classifications of Turkey and assist them in figuring out ways in which they might contribute to the literature, either by criticizing the existing paradigms or by enhancing them.

5 Ayşe Bugra and Aysen Candas, "Change and Continuity under an Eclectic Social Security Regime: The Case of Turkey," Middle Eastern Studies 47, no. 3 (2011): 515-528.

6 Abu Sharkh and Gough, "Global Welfare Regimes: A Cluster Analysis."

7 Ayşe Buğra and Çağlar Keyder, "New Poverty and the Changing Welfare Regime of Turkey" (Ankara: UNDP, 2003); John Gal, "Is There an Extended Family of Mediterranean Welfare States?" Journal of European Social Policy 20, no. 4 (2010): 283-300; Ian Gough, "Social Assistance in Southern Europe," South European Society \& Politics 1, no. 1 (1996): 1-23.

8 Asena Günal, "Health and Citizenship in Republican Turkey: An Analysis of the Socialization of Health Services in Republican Historical Context” (Ph.D. dissertation, Bogaziçi University, 2008); Bob Deacon and Paul Stubbs, eds. Social Policy and International Interventions in South East Europe (Cheltenham, UK and Northampton, MA: Edward Elgar Publishing, 2007).

9 Tülay Arın, "The Poverty of Social Security: The Welfare Regime in Turkey," in The Ravages of Neoliberalism: Society and Gender in Turkey, ed. Neşecan Balkan and Sungur Savran (New York: Nova Science Publishers, 2002): 73-91.

10 Rana Jawad, Social Welfare and Religion in the Middle East: A Lebanese Perspective (Bristol: Policy Press, 2009).

11 John Hudson and Stefan Kühner, "Analyzing the Productive and Protective Dimensions of Welfare: Looking Beyond the OECD," Social Policy \& Administration 46, no. 1 (February 1, 2012): 35-60.

12 Tuba Inci Ağartan, "Turkish Health System in Transition: Historical Background and Reform Experience" (Ph.D. dissertation, Binghamton University, 2008). 
As will be demonstrated, most scholars have classified Turkey as part of the "Southern European" welfare regime sub-family. This paradigmatic Southern European framework has arguably weakened the possibility of considering Turkey according to any other alternative welfare regime models. As will be shown in the next section, the empirical data from Turkey's welfare system, including coverage and expenditure on different social programs, indicate that Turkey's welfare regime seems to have been transformed from a corporatist/ Southern European model into a new model that exemplifies characteristics of both liberal and social democratic models, possibly implying an overall new welfare regime. It can thus be argued that Turkey's welfare regime may be joining a welfare regime family of emerging market economies, in which income-based social assistance programs constitute the central element of an expanding welfare state. Our analysis, as will be seen, indicates that none of the studies that has examined Turkey has considered the possibility that the Turkish welfare regime may have embarked in just such a novel direction.

\section{The Turkish welfare regime}

Esping-Andersen's welfare regime approach ${ }^{13}$ appears to have relevance to the Turkish case. Many scholars have argued that the configurations of welfare provision in Turkey comply with the analytical requirements of "being a regime," ${ }^{14}$ as welfare is generated within a tripartite relationship among state, family, and the market. The key axes of Esping-Andersen's approachdecommodification, stratification, and defamilialization-are critical to understanding the case of Turkey. Dispossession and rapid rural-to-urban migration have brought about an extensive commodification of labor, and the existing welfare regime has developed institutions for the protection of private and public sector employees for the purpose of decommodification. The welfare system is certainly hierarchical, and it has produced stratification of varying degrees and types in different decades of Turkish welfare regime development. Familialization is also a critical dimension in the Turkish case, as the welfare system can be shown to shape women's place in the family and in society, with

13 Esping-Andersen, The Three Worlds of Welfare Capitalism; Gøsta Esping-Andersen, Social Foundations of Postindustrial Economies (Oxford: Oxford University Press, 1999).

14 Arın, "The Poverty of Social Security"; Buğra and Keyder, "New Poverty and the Changing Welfare Regime"; Ayşe Buğra and Çağlar Keyder, "The Turkish Welfare Regime in Transformation," Journal of European Social Policy 16, no. 3 (August 1, 2006): 211-228; Ayşe Bugra and Aysen Candas, "Change and Continuity under an Eclectic Social Security Regime: The Case of Turkey," Middle Eastern Studies 47, no. 3 (2011): 515-528; Eder, "Retreating State?"; Daniel Grütjen, “The Turkish Welfare Regime: An Example of the Southern European Model? The Role of the State, Market and Family in Welfare Provision," Turkish Policy Quarterly 7, no. 1 (2008): 111-129. 
women's emancipation from family ties being strengthened and weakened by different sets of welfare policies constructed in different political periods. ${ }^{15}$

The roots of the social welfare system in Turkey can be traced back to the endowment (waqf) systems of the Ottoman Empire. Since then, welfare provision has been shaped by both European welfare systems and traditional Islamic values of charity. ${ }^{16}$ As in many other middle-income countries, there were moves toward a modern welfare system after World War II, including the establishment of the Ministry of Labor and Social Security (Çalışma ve Sosyal Güvenlik Bakanliğı) in 1945, but a welfare system containing both formal and informal components remained in place until the 1990 s. ${ }^{17}$

Before the 2000s, the Turkish welfare system was based on a corporatist fragmented social provision, in which employees in the state sector, workers, and the self-employed were members of different institutions with different qualities of service and different benefits. Since the turn of the new millennium, a new welfare system has largely eliminated this fragmented structure, creating a social security institution and a general health insurance system to cover all citizens. Within this structure, social welfare programs aimed at the informal poor, most importantly healthcare, have been equalized with those aimed at formal sector employees. In this universal healthcare system, all citizens are covered and the premiums of formal sector employees are paid by the employees, with the premiums of the informal poor being paid by the government and the premiums of the informal non-poor recently being lowered to almost 15 US dollars. The quality of healthcare has significantly improved, which has often been regarded as one of the main pillars of the social policies of the ruling Justice and Development Party (Adalet ve Kalkinma Partisi, AKP). ${ }^{18}$ As a result, Turkish welfare system expenditures as a percentage of the GDP have increased from 3.1 percent in 1980 to 12.5 percent in $2013 .{ }^{19}$

This expansion has been accompanied by a restructuring of welfare provision from fragmented employment-based social security policies to

15 Saniye Dedeoglu, "Veiled Europeanisation of Welfare State in Turkey: Gender and Social Policy in the 2000s," Women's Studies International Forum 41, no. 1 (2013): 7-13; Adem Y. Elveren, "Social Security Reform in Turkey: A Critical Perspective," Review of Radical Political Economics 40, no. 2 (2008): 212-232; Azer Kılıç, "The Gender Dimension of Social Policy Reform in Turkey: Towards Equal Citizenship?" Social Policy \& Administration 42, no. 5 (2008): 487-503.

16 Elveren, "Social Security Reform in Turkey."

17 Grütjen, "The Turkish Welfare Regime"; Buğra and Keyder, "The Turkish Welfare Regime in Transformation."

18 Erdem Yörük, "The Politics of the Turkish Welfare System Transformation in the Neoliberal Era: Welfare as Mobilization and Containment" (Ph.D. dissertation, The Johns Hopkins University, 2012).

19 Organisation for Economic Co-operation and Development (OECD), "Social Expenditure Aggregated Data," 2012. http://stats.oecd.org/Index.aspx?datasetcode=SOCX_AGG. 
income-based social services and social assistance policies. ${ }^{20}$ In 2011, the Ministry of Family and Social Policy (Aile ve Sosyal Politikalar Bakanliğt) was established to administer central government programs and to introduce new social assistance programs. The ministry's budget increased from 955 million US dollars in 2002-when the relevant affairs were dealt with by a separate agency - to 11.6 billion US dollars in 2014. The ratio of social expenditures to the GNP increased from 0.5 percent to 1.51 percent during the same period. ${ }^{21}$ Moreover, between 2000 and 2010, the percentage of social assistance spending in total government spending increased by 266 percent. ${ }^{22}$ The government has drastically expanded means-tested social assistance, in kind or cash transfers, as well as providing free healthcare programs for the poor, conditional cash transfers, programs for orphans, food stamps, housing, education and disability aid for the poor, and sharply increasing the number of beneficiaries and the share of government budgets allocated. ${ }^{23}$ The coverage of the free healthcare card program for the poor (the Green Card or Yeşil Kart program) increased from 4.2 to 12.7 percent of the population between 2003 and 2009, and in 2012, Green Card holders were included in the new universal healthcare system. ${ }^{24}$ As such, the regular in-kind and cash benefits granted by the central government to a poor family adds up to 260 US dollars, while the official minimum wage in Turkey is 370 US dollars. ${ }^{25}$

The government has also initiated social housing programs targeting the poor, which provide houses on cheap credit and covered over three million families by 2013. Furthermore, the Ministry of National Education (Millî Eğitim Bakanliğı) distributed all school coursebook materials free of charge to all students in primary and secondary education, amounting to 15 million students. Each year, 600,000 students also take part in the free school transportation program, which provides free lunch at schools as well.

20 Buğra and Keyder, "New Poverty and the Changing Welfare Regime"; Günal, "Health and Citizenship in Republican Turkey”; Erdem Yörük, "Welfare Provision as Political Containment: The Politics of Social Assistance and the Kurdish Conflict in Turkey," Politics \& Society 40, no. 4 (December 1, 2012): 517-547.

21 "Aile ve Sosyal Politikalar Bakanlığının 2015 yılı bütçesinin görüşmeleri TBMM Plan ve Bütçe Komisyonu'nda tamamlandı," November 6, 2014, http://www.aile.gov.tr/haberler/aile-vesosyal-politikalar-bakanliginin-2015-yili-butcesinin-gorusmeleri-tbmm-plan-ve-butce-komisyonundatamamlandi.

22 Emre Üçkardeşler, "Turkey's Changing Social Policy Landscape," Turkish Policy Quarterly 13, no. 4 (2015): 149-161.

23 Buğra and Keyder, "The Turkish Welfare Regime in Transformation"; Yörük, "Welfare Provision as Political Containment"; Elveren, "Social Security Reform in Turkey"; Günal, "Health and Citizenship in Republican Turkey"; Çağri Yoltar, "When the Poor Need Health Care: Ethnography of State and Citizenship in Turkey," Middle Eastern Studies 45, no. 5 (1 September 2009): 769-782.

24 Yörük, "Welfare Provision as Political Containment."

25 Bahadır Özgür, "işte Ak Parti'nin 'Sosyal Yardım' Gerçeği!" Radikal, December 29, 2014, http://www. radikal.com.tr/politika/iste-ak-partinin-sosyal-yardim-gercegi-1260849/. 
The government has put into the constitution affirmative action policies for disabled people, which greatly increased their participation in the labor market, and what is more, since 2002, the coverage of disability benefits has tripled, while the amount of per capita payments has doubled. This is also the case for old age pensions for the poor. Most importantly, if a poor family provides nursing to a disabled family member or elderly person, it receives an amount almost equal to the minimum wage. Similarly, a new program granted poor grandparents a monthly wage of more than 100 US dollars for providing daycare for their grandchildren.

With its current structure, the Turkish welfare system could be considered part of an emerging welfare regime family together with other emerging market economies. Piven and Minnite argue that this emerging family signifies a bifurcation in the global welfare system: while advanced capitalist countries have undergone significant welfare retrenchments that reduced the capacity to decommodify labor and level out inequalities, emerging market economies have expanded their welfare states, mostly on the basis of novel types of social assistance programs that have significant decommodifying effects. ${ }^{26}$ Similarly, the International Labour Organization (ILO) argues that a bifurcation is occurring between an eroding "European social model" and a rising "inclusive growth through social protection" model in emerging markets. ${ }^{27}$ Over the last three decades, many emerging market economies have rapidly expanded their social assistance programs and services for the poor by increasing program coverage and benefits and by relaxing the terms and conditions of eligibility, while in most developed countries social assistance-type schemes continue to have a more residual role. ${ }^{28}$

\section{Data and Analysis}

This study is based on a structured search for all studies that have attempted to classify the Turkish welfare regime. The parameters for the search aim to discover those sources that focus on social welfare (rather than economic classifications) in Turkey and that involve placing the country within some sort of typology, classification, or grouping. Two searches were carried out, using

26 Frances Fox Piven and Lorraine C. Minnite, "Poor People's Politics," in The Oxford Handbook of the Social Science of Poverty, ed. David Brady and Linda M. Burton (Oxford: Oxford University Press, 2016): 751-773; Frances Fox Piven and Lorraine C. Minnite, "Crisis, Convulsion and the Welfare State," in Social Policy in Times of Austerity: Towards a New International Political Economy of Welfare, ed. Kevin Farnsworth and Zoe Irving (Bristol: Policy Press, 2015): 143-170.

27 International Labour Organization (ILO), World Social Protection Report: Building Economic Recovery, Inclusive Development and Social Justice, 2014-15 (Geneva: International Labour Office, 2015).

28 World Bank, The State of Social Safety Nets 2015 (Washington, DC: World Bank, 2015). 
the same search terms in the English and Turkish languages. The search for this article was carried out on the Scopus database in April 2016, using the following search terms:

\section{Turk\$ AND 'social welfare' AND regime\$ OR class OR typ\$}

The English-language search produced 58 results. The main criterion for inclusion was that the article had to classify Turkey within a regime, model, or cluster. Snowballing was carried out, with the final number of studies being 28 . The Turkish-language search initially produced 18 results, including 10 articles and 7 books. Application of the inclusion criteria produced 6 studies.

\section{Studies written in English}

Studies written in English can be classified into three broad approaches to classifying Turkey: large- or medium-N global studies; "regional studies," although there is limited consensus on the "region" in question (see below); and single-country case studies.

Large- $N$ studies. The articles in this category are generally "large-N", statistically classifying a large number of countries on the basis of data from sources such as the OECD via techniques such as cluster analysis. We will demonstrate that there is no consensus among "large-N" studies on the classification of the Turkish welfare regime. Gough regarded Turkey as part of the Southern European or Mediterranean welfare regime cluster. ${ }^{29}$ Eardley et al. identified at least seven "social assistance regimes," placing Turkey in the "rudimentary assistance" regime, together with the countries of southern Europe. ${ }^{30}$ Gough et al, $\mathrm{s}^{31}$ analysis of social assistance in OECD countries slightly modified Eardley et al. to find eight "social assistance regimes"; however, Turkey was again considered as part of the "rudimentary assistance" regime, along with Italy, Spain, Portugal, and Greece. Gough ${ }^{32}$ further noted that the eight "social assistance regimes" identified by Gough et al. derived from their own judgements, though now he used cluster analysis on the same data so as to test their earlier judgements. Due to inadequate data, Iceland, Italy, the Netherlands, and Turkey were excluded from the analysis, leaving 20 countries. The best solution produced seven clusters: the "minimal extent, exclusive, very low

29 Gough, "Social Assistance in Southern Europe."

30 Tony Eardley et al., Social Assistance in OECD Countries (London: HM Stationery Office, 1996). https:// www.york.ac.uk/inst/spru/pubs/pdf/rrep046.pdf.

31 lan Gough et al., "Social Assistance in OECD Countries," Journal of European Social Policy 7, no. 1 (February 1, 1997): 17-43.

32 Ian Gough, "Social Assistance Regimes: A Cluster Analysis," Journal of European Social Policy 11, no. 2 (May 1, 2001): 165-170. 
benefits" cluster included "Greece, Portugal (Turkey?)," with the closest 1997 grouping being Greece, Italy, Portugal, Spain, and Turkey. In other words, it appeared that the classification of Turkey (which was excluded due to inadequate data) was a best guess. Gough claimed that his results challenged EspingAndersen's threefold division of welfare regimes, as there were divisions within the Mediterranean sub-regime as well, suggesting that this fourth regime was not fully cohesive. He also changed his view, overturning his earlier assertion ${ }^{33}$ that there was a distinctive Southern European assistance regime.

Abu Sharkh and Gough ${ }^{34}$ carried out cluster analysis on 65 nations. They found four substantial cluster groups in 1990 and eight clusters in 2000. In both years, Turkey was in Cluster B ("Successful Informal Security Regime"), which contained 21 countries in 1990 (one-third of the total, representing several world regions, together with Iran and Tajikistan) and a more complex cluster of 16 countries in 2000 (together with Iran). They pointed out that the countries in this group were primarily, but not necessarily, low-middle income with high growth rates, but were relatively undemocratic and unequal. Moreover, it was a disparate group in cultural and historical terms.

Gough and Abu Sharkh ${ }^{35}$ explored how the composition of public revenues in terms of sources (e.g., taxation, social insurance contributions, mineral rents, and foreign aid) is associated with different welfare regimes and social policy outcomes. Using cluster analysis, they identified four clusters of countries where one form of revenue is dominant, and a fifth where this was not the case. The cluster with substantial tax revenues was, unexpectedly, limited to just two world regions: the Middle East and North Africa (MENA), and southern and eastern Africa. Every MENA country for which they had data, excepting only Yemen and Iran, was in this group. Cluster B, however, contained considerable variation, with Turkey ( 20 percent of GDP), Chile (17 percent), and Korea (16 percent) recording tax revenues higher than many in cluster A. They concluded that the Gough-Wood label "informal security regime" did not do full justice to such countries.

Rudra $^{36}$ argued that not all least developed countries (LDCs) have "productive welfare states" that direct welfare efforts primarily toward encouraging wage labor. Using a combination of policy, spending, and outcome (i.e., literacy, mortality, and immunization rates) variables, she carried out a cluster analysis of 32 nations, with a three-group solution being the most distinct solution. Clusters 1 and 3 appeared to favor the productive and

33 Gough, "Social Assistance in Southern Europe."

34 Abu Sharkh and Gough, "Global Welfare Regimes: A Cluster Analysis."

35 Gough and Abu Sharkh, "Financing Welfare Regimes."

36 Rudra, "Welfare States in Developing Countries." 
protective components of welfare, respectively. Turkey was in Cluster 3, together with 12 countries-including Egypt, Iran, Tunisia and Moroccowhile Cyprus, Greece, Israel, and Kuwait were in Cluster 1.

Hudson and Kühner ${ }^{37}$ examined the protective and productive dimensions of welfare for 55 high- and higher-middle-income countries by means of fuzzy set ideal type analysis (FSITA). They used data on income protection, employment protection, training investment, education investment, and the percentage of non-wage workers in total employment. Turkey was placed in the "Productive Plus" group, which also included Denmark, Estonia, Norway, Poland, and Mexico. They concluded that welfare state types did not simply interface with regional blocs in terms of the balance between welfare's productive and protective dimensions.

A $\operatorname{artan}^{38}$ regarded Turkey as an "inegalitarian corporatist system" that guaranteed employment-related benefits for most formal sector workers but excluded wide sections of the population. In a section entitled "Theorizing Turkish Welfare Regime," she argued that, of Seeking's ${ }^{39}$ three types, the Turkish welfare system seems to best be described by the "inegalitarian corporatist" type: a formal social insurance system that provides social protection to privileged groups and excludes rural populations and the urban poor. ${ }^{40}$ Turning to Gough et al., ${ }^{41}$ she noted that, while Turkey is not included in the analysis except for a brief reference, with its above-average welfare outcomes in all areas-i.e., life expectancy, literacy, and freedom from poverty-and its belowaverage levels of public expenditure, it seems to belong to either their first or second category. She continued that, after 1960, the Turkish welfare system attained a dual character that, to use Gough et al.'s terminology, ${ }^{42}$ combined elements of a welfare state regime and an informal security regime. She further noted that, while the Turkish welfare regime had been undergoing major transformation since the mid-1990s, it was nevertheless not possible to argue that the Turkish welfare system had evolved towards a European-type welfare state. Rather, a dual welfare structure emerged, consisting of formal social security schemes for industrial workers and civil servants and an informal welfare system to provide some degree of protection to those left out of the formal system.

37 Hudson and Kühner, "Analyzing the Productive and Protective Dimensions of Welfare."

38 Ağartan, "Turkish Health System in Transition."

39 Seekings, "Prospects for Basic Income in Developing Countries."

40 It should also be noted, however, that Seekings considered that Islamic nations might form a fourth cluster, since in such nations charity is a mechanism for maintaining minimum incomes separate from the market, the state, and kin.

41 Gough, "East Asia: The Limits of Productivist Regimes."

42 Ian Gough et al., Insecurity and Welfare Regimes in Asia, Africa, and Latin America: Social Policy in Development Contexts (Cambridge, UK and New York: Cambridge University Press, 2004). 
Aysan ${ }^{43}$ analyzed the Turkish pension system and pension reforms in relation to welfare regime discussions. He stated that, among the G20 and OECD countries, Turkey, with its contradictory socioeconomic features, emerged as an unusual case. Contrary to claims that the Turkish welfare state and social assistance system were residual, ${ }^{44}$ he argued that the Turkish state had a significant role in welfare distribution, particularly regarding the elderly. Examining eleven pension and labor market variables for the period of 2009-2011 for 19 OECD nations, he performed a cluster analysis that revealed three broad pension regimes: Southern European, Continental European, and social-liberal. The Southern European regime included Greece, Spain, and Turkey (as well as Denmark, though Italy joined the Continental European group while Portugal merged with the social-liberal group). He concluded that Turkey can be considered under the Southern European welfare regime, which is a distinct welfare regime with mixed features of citizenship-based Beveridgean universal national health services and occupation-based Bismarckian income transfers.

As shown in Table 1, all these studies are very diverse in terms of the number of countries they consider, as well as in terms of their underlying concepts and variables. Most importantly, there is little consensus as to the classification of Turkey, which is placed under a number of different headings and classed alongside a diverse mixture of other countries.

Regional Studies. The regional approach is based on the assumption that geographical location is the key to classification. In other words, clusters of nations are not based on characteristics produced by techniques such as cluster analysis, but rather on geographical location. "Regions," therefore, are made up of neighboring countries. However, as we shall see, there appears to be little consensus about which region Turkey should be placed in, as a wide variety of terms with different constituent nations, have been used, sometimes even by the same author: e.g., the Arab region; ${ }^{45}$ the Middle East; ${ }^{46}$ the Middle East

43 Mehmet Fatih Aysan, "Reforms and Challenges: The Turkish Pension Regime Revisited," Emerging Markets Finance and Trade 49, no. sup5 (2013): 148-162.

44 Burcu Yakut-Cakar, "Turkey," in Social Policy and International Interventions in South East Europe, ed. Bob Deacon and Paul Stubbs (Cheltenham, UK and Northampton, MA: Edward Elgar Publishing, 2007): 103-129; Buğra and Keyder, "The Turkish Welfare Regime in Transformation."

45 Valentine M. Moghadam, "The Political Economy of Female Employment in the Arab Region," in Gender and Development in the Arab World: Women's Economic Participation, Patterns and Policies, ed. Nabil F. Khoury and Valentine M. Moghadam (London: Zed Books, 1995): 6-34.

46 Valentine M. Moghadam, Modernizing Women: Gender and Social Change in the Middle East (Boulder: Lynne Rienner Publishers, 2003); Massoud Karshenas and Valentine M. Moghadam, "Social Policy in the Middle East: Introduction and Overview," in Social Policy in the Middle East: Economic, Political and Gender Dynamics, ed. Massoud Karshenas and Valentine M. Moghadam (Basingstoke: Palgrave Macmillan, 2006): 1-30. 
Table 1. Classification and Analysis of Studies on Turkish Welfare Regime (English-Language Studies)

\begin{tabular}{|c|c|c|c|c|c|}
\hline Study & Concepts & Criteria/Variables & Method & Cluster & $\begin{array}{c}\text { \# of } \\
\text { Citations }\end{array}$ \\
\hline $\begin{array}{l}\text { Abu Sharkh and } \\
\text { Gough (2010) }\end{array}$ & $\begin{array}{l}\text { Welfare regimes defined } \\
\text { as combinations of } \\
\text { institutions and welfare } \\
\text { outcomes }\end{array}$ & $\begin{array}{l}\text { Aid per capita/GNI; } \\
\text { workers' remittances/ GNI; public } \\
\text { spending on health + education/ } \\
\text { GDP; social contributions (\% of total } \\
\text { revenue); immunization, measles (\% of } \\
\text { children under } 12 \text { months); school } \\
\text { enrollment, secondary, female } \\
\text { (\% gross); life expectancy at birth, total } \\
\text { (years); illiteracy rate, youth total } \\
\text { (\% of people ages } 15-24)\end{array}$ & $\begin{array}{l}\text { Data on } 65 \text { countries in } \\
1990 \text { and 2000; } \\
\text { hierarchical and } \\
\text { K clustering }\end{array}$ & $\begin{array}{l}\text { Turkey in Cluster B (Successful } \\
\text { Informal Security Regimes) in both } \\
1990 \text { and 2000, with } 20 \text { and } 15 \\
\text { other countries respectively }\end{array}$ & 63 \\
\hline A ğartan (2008) & $\begin{array}{l}\text { Transformation of } \\
\text { Turkish welfare regime }\end{array}$ & Draws on Seekings and Gough & Discussion & $\begin{array}{l}\text { Turkey is an "informal security regime" } \\
\text { (Gough); a dual character that } \\
\text { combines elements of a welfare state } \\
\text { regime and an informal security } \\
\text { regime, and "inegalitarian } \\
\text { corporatist" (Seekings) }\end{array}$ & 8 \\
\hline Akan (2011) & $\begin{array}{l}\text { Conservative democratic } \\
\text { social policy }\end{array}$ & $\begin{array}{l}\text { Responsible pragmatism; Islamism; } \\
\text { liberalism }\end{array}$ & Discussion & $\begin{array}{l}\text { Turkish social policy is more a "ragtag } \\
\text { collection" than a regime per se }\end{array}$ & 9 \\
\hline $\begin{array}{l}\text { Aybars and } \\
\text { Tsarouhas } \\
\text { (2010) }\end{array}$ & $\begin{array}{l}\text { Extending welfare regimes } \\
\text { to the Middle East }\end{array}$ & $\begin{array}{l}\text { Gender ("neopatriarchal" state); } \\
\text { influence of religion (Islam); prone to } \\
\text { external intervention }\end{array}$ & Discussion & $\begin{array}{l}\text { "Hybrid" character of the Turkish } \\
\text { welfare regime, illustrating important } \\
\text { features of both the Middle Eastern } \\
\text { and Southern European welfare } \\
\text { models, but remaining an outlier to } \\
\text { both in certain respects }\end{array}$ & 17 \\
\hline
\end{tabular}


Table 1. (Continued)

\begin{tabular}{|c|c|c|c|c|c|}
\hline Study & Concepts & Criteria/Variables & Method & Cluster & $\begin{array}{c}\text { \# of } \\
\text { Citations }\end{array}$ \\
\hline Aysan (2013) & Pension regimes & $\begin{array}{l}\text { Eleven pension and labor market } \\
\text { variables for 2009-2011 for } 19 \\
\text { OECD nations }\end{array}$ & Hierarchical cluster analysis & $\begin{array}{l}\text { Southern European regime (Turkey, } \\
\text { with Greece, Spain, and Denmark) }\end{array}$ & 3 \\
\hline $\begin{array}{l}\text { Buğgra and Keyder } \\
\quad(2003)\end{array}$ & Social policy & $\begin{array}{l}\text { Structure of employment; properties of } \\
\text { formal social policy institutions; and } \\
\text { informal social integration } \\
\text { mechanisms }\end{array}$ & Secondary literature analysis & Southern European & 151 \\
\hline $\begin{array}{l}\text { Buğra and Candas } \\
\quad(2011)\end{array}$ & Eclectic social security & $\begin{array}{l}\text { Dual citizenship model with a } \\
\text { Bismarckian formal social security } \\
\text { system that also incorporates } \\
\text { informality and clientelism }\end{array}$ & $\begin{array}{l}\text { Discussion of the secondary } \\
\text { literature and historical } \\
\text { analysis of welfare } \\
\text { transformation }\end{array}$ & Southern European & 46 \\
\hline $\begin{array}{l}\text { Buğra and Keyder } \\
\quad(2006)\end{array}$ & New poverty & $\begin{array}{l}\text { Historical legacy of state-society } \\
\text { relations in the country and } \\
\text { conservative liberalism of the current } \\
\text { government }\end{array}$ & $\begin{array}{l}\text { Qualitative analysis of the } \\
\text { secondary literature and } \\
\text { social welfare indicators }\end{array}$ & Southern European & 178 \\
\hline Dedeoglu (2013) & Gender & "Veiled Europeanisation" & Discussion & $\begin{array}{l}\text { Synthesis of neoliberalism and Islamic } \\
\text { notions of social solidarity; women's } \\
\text { status in the Turkish welfare system } \\
\text { shows a dualistic character of "veiled } \\
\text { Europeanisation" between the } \\
\text { Middle East and European countries }\end{array}$ & 10 \\
\hline $\begin{array}{l}\text { Eardley et al. } \\
\qquad(1996)\end{array}$ & $\begin{array}{l}\text { Social assistance regimes in } \\
\text { OECD countries }\end{array}$ & $\begin{array}{l}\text { Three dimensions of countries' social } \\
\text { assistance systems: extent, program } \\
\text { structure, and generosity }\end{array}$ & $\begin{array}{l}\text { Data on social assistance, but } \\
\text { "judgement" }\end{array}$ & $\begin{array}{l}\text { Rudimentary assistance regime } \\
\text { (7 regimes })\end{array}$ & 32 \\
\hline
\end{tabular}


Table 1. (Continued)

\begin{tabular}{|c|c|c|c|c|c|}
\hline Study & Concepts & Criteria/Variables & Method & Cluster & $\begin{array}{c}\text { \# of } \\
\text { Citations }\end{array}$ \\
\hline Eder (2009) & $\begin{array}{l}\text { Expansion and retreat of } \\
\text { state power }\end{array}$ & Welfare mix & Data on welfare provision & Mutated "institutional welfare-mix" & 40 \\
\hline Gal (2010) & $\begin{array}{l}\text { Loosely based on the } \\
\text { "family of nations" } \\
\text { approach }\end{array}$ & Commonalities between welfare states & $\begin{array}{l}\text { Data on welfare provision } \\
\text { (graphs) }\end{array}$ & $\begin{array}{l}\text { "Extended family of Mediterranean } \\
\text { welfare states" of eight nations } \\
\text { (Turkey, Cyprus, Greece, Israel, } \\
\text { Italy, Malta, Spain, and Portugal) }\end{array}$ & 93 \\
\hline $\begin{array}{l}\text { Gencler and Colak } \\
\text { (2012) }\end{array}$ & $\begin{array}{l}\text { Welfare regimes/ Southern } \\
\text { Model }\end{array}$ & Characteristics of "Southern model" & $\begin{array}{l}\text { Social expenditure and } \\
\text { discussion of reforms }\end{array}$ & Southern European Model & 0 \\
\hline Gough (1996) & Social assistance & $\begin{array}{l}\text { Characteristics of "Southern model"; } \\
\text { rudimentary welfare system }\end{array}$ & Data on social assistance & $\begin{array}{l}\text { Distinctive Southern European } \\
\text { assistance regime }\end{array}$ & 174 \\
\hline
\end{tabular}

Gough et al. (1997) Social assistance in OECD Three dimensions of social assistance countries

systems: extent, program structure, and generosity

Data on social assistance, but Slightly modifies Eardley et al. (1996) "judgement"

Cluster analysis; Turkey excluded due to inadequate data but included (with a question mark) in classification; i.e., best guess? benefit levels after housing costs and relative benefit levels after housing costs) expenditure/GDP and SA recipients/ total population); structure (exclusion to find eight "social assistance regimes"; Turkey considered part of the "rudimentary assistance" regime with Italy, Spain, Portugal, and Greece

"Minimal extent, exclusive, very low benefits" cluster included "Greece, Portugal (Turkey?)," with the closest 1997 grouping being Greece, Italy, Portugal, Spain, and Turkey (7 clusters); illustrates divisions within the Mediterranean subregime, which overturns the view of Gough (1996) that there is a distinctive Southern European assistance regime 
Table 1. (Continued)

\begin{tabular}{|c|c|c|c|c|c|}
\hline Study & Concepts & Criteria/Variables & Method & Cluster & $\begin{array}{c}\text { \# of } \\
\text { Citations }\end{array}$ \\
\hline $\begin{array}{l}\text { Gough and } \mathrm{Abu} \\
\text { Sharkh (2011) }\end{array}$ & Revenue systems & $\begin{array}{l}\text { Public revenues in terms of sources } \\
\text { (e.g., taxation, social insurance, } \\
\text { mineral rents, foreign aid) }\end{array}$ & Cluster analysis & $\begin{array}{l}\text { Turkey in Cluster B: substantial } \\
\text { taxation, with MENA and South } \\
\text { and East African nations }\end{array}$ & 10 \\
\hline Grütjen (2008) & Welfare regimes & Traits of Southern European Model & $\begin{array}{l}\text { Tables comparing Turkey } \\
\text { with nations of Southern } \\
\text { Europe, and } \\
\text { representatives of three } \\
\text { worlds }\end{array}$ & Southern European Model & 21 \\
\hline $\begin{array}{l}\text { Henry and } \\
\text { Springborg } \\
(2001)\end{array}$ & Development & $\begin{array}{l}\text { Islam and the tradition of external } \\
\text { intervention }\end{array}$ & $\begin{array}{l}\text { Comparative historical } \\
\text { analysis, with descriptive } \\
\text { statistics }\end{array}$ & Middle East and North Africa & 481 \\
\hline $\begin{array}{l}\text { Hudson and } \\
\text { Kühner (2012) }\end{array}$ & $\begin{array}{l}\text { Protective and productive } \\
\text { dimensions of welfare }\end{array}$ & $\begin{array}{l}\text { Data on income protection, employment } \\
\text { protection, training investment, } \\
\text { education investment, and the } \\
\text { percentage of non-wage workers in } \\
\text { total employment }\end{array}$ & $\begin{array}{l}\text { Fuzzy set ideal type analysis } \\
\text { (FSITA) for } 55 \text { high- and } \\
\text { higher-middle-income } \\
\text { nations }\end{array}$ & $\begin{array}{l}\text { Turkey in the "productive plus" group } \\
\text { that also includes Denmark, Estonia, } \\
\text { Norway, Poland, and Mexico; } \\
\text { welfare state types do not simply } \\
\text { interface with regional blocs when it } \\
\text { comes to the balance between } \\
\text { productive and protective } \\
\text { dimensions of welfare }\end{array}$ & 26 \\
\hline Jawad $(2008,2009)$ & Religion & $\begin{array}{l}\text { Revised history of social policy in } \\
\text { the region }\end{array}$ & $\begin{array}{l}\text { Review of secondary } \\
\text { literature }\end{array}$ & Residual welfare state of MENA region & $\begin{array}{l}2(2008) ; \\
31(2009)\end{array}$ \\
\hline Kılıç (2008) & Gender and citizenship & $\begin{array}{l}\text { Gender dimension of social security } \\
\text { reform; breadwinner models }\end{array}$ & Discussion & $\begin{array}{l}\text { Southern European: multi-fragmented, } \\
\text { corporatist social security system }\end{array}$ & 36 \\
\hline Manning (2007) & $\begin{array}{l}\text { Likely impact of EU on } \\
\text { social policy }\end{array}$ & $\begin{array}{l}\text { Strong state and a family-centered } \\
\text { tradition }\end{array}$ & Discussion & Latin Rim & 12 \\
\hline
\end{tabular}


Table 1. (Continued)

\begin{tabular}{|c|c|c|c|c|c|}
\hline Study & Concepts & Criteria/Variables & Method & Cluster & $\begin{array}{c}\text { \# of } \\
\text { Citations }\end{array}$ \\
\hline Morvaridi (2013) & $\begin{array}{l}\text { Philanthropy, patronage, } \\
\text { clientelism }\end{array}$ & $\begin{array}{l}\text { Faith-based philanthropy; welfare } \\
\text { governance }\end{array}$ & Discussion & Neoliberal welfare & 11 \\
\hline Rudra (2007) & $\begin{array}{l}\text { Protective and productive } \\
\text { elements }\end{array}$ & $\begin{array}{l}\text { Policy, spending, and outcome variables } \\
\text { (literacy, mortality, and immunization } \\
\text { rates) }\end{array}$ & $\begin{array}{l}\text { Cluster analysis of } 32 \\
\text { nations }\end{array}$ & $\begin{array}{l}\text { Turkey in Cluster } 3 \text { (containing both } \\
\text { protective and productive elements), } \\
\text { with } 12 \text { countries, including Egypt, } \\
\text { Iran, Tunisia, and Morocco }\end{array}$ & 136 \\
\hline Şentürk (2014) & $\begin{array}{l}\text { Family, community, } \\
\text { neighborhoods, } \\
\text { hometowns, and political } \\
\text { affiliations }\end{array}$ & Government and NGO activity & Discussion & Southern European & 0 \\
\hline $\begin{array}{l}\text { Yakut-Çakar } \\
\text { (2007) }\end{array}$ & $\begin{array}{l}\text { Corporatism, family, } \\
\text { residual social assistance } \\
\text { system }\end{array}$ & $\begin{array}{l}\text { Social policy developments in Turkey } \\
\text { with a particular focus on the role of } \\
\text { international actors }\end{array}$ & $\begin{array}{l}\text { Data on employment and } \\
\text { welfare provision (tables) }\end{array}$ & Southern European & $\begin{array}{l}58 \text { (for } \\
\text { edited } \\
\text { volume } \\
\text { rather } \\
\text { than } \\
\text { chapter) }\end{array}$ \\
\hline
\end{tabular}


and North Africa (MENA); "South Eastern Europe"; ${ }^{48}$ Southern Europe; ${ }^{49}$ an extended family of Mediterranean nations; ${ }^{50}$ or a hybrid Southern Europe/ MENA model, reflecting Turkey's place straddling the two continents. ${ }^{51}$

Henry and Springborg ${ }^{52}$ classified Turkey as one of the 22 countries within the MENA region, which is defined by Islam and the tradition of external intervention. Manning ${ }^{53}$ claimed that, in terms of welfare state classification, Turkey has less in common with Esping-Andersen's core types than with the so-called "Latin Rim," where a strong state and a family-centered tradition prevailed. Deacon and Stubbs ${ }^{54}$ classified Turkey as "inegalitarian corporatist," but noted that it is an outlier within South East Europe, as it was the only state that lacked a commitment to universal health and education.

Grütjen $^{55}$ argued that Turkey fit the key characteristics of the ideal type of the Southern European Model, as cross-national comparison revealed only a few deviations from this model, while the predominance of the state and family in social provision was striking. For this, he cited the World Bank's claim ${ }^{56}$ that it is "difficult to overstate the importance of marriage, family and extended family ties" in the Turkish context. He used the key characteristics of the Southern European Model of welfare to classify the Turkish welfare regime: comparing data from Turkey and the four representatives of the Southern European Model (Spain, Italy, Portugal, and Greece), as well as representatives (the United Kingdom, Sweden, and Germany) of the three welfare regimes outlined by Esping-Andersen, he emphasized the similarities between Turkey and Southern Europe. His argument was that, in Turkey much as in Southern Europe, the social security system is polarized and protects an occupational core, the level of state penetration in the social realm is extremely low, and a safety net in the form of a social assistance scheme is absent. The most

47 Valentine M. Moghadam, Women, Work, and Economic Reform in the Middle East and North Africa (Boulder: Lynne Rienner, 1998); Dedeoglu, "Veiled Europeanisation of Welfare State in Turkey"; Karshenas and Moghadam, "Bringing Social Policy Back in"; Massoud Karshenas, Valentine M. Moghadam, and Randa Alami, "Social Policy after the Arab Spring: States and Social Rights in the MENA Region," World Development 64 (2014): 726-739.

48 Deacon and Stubbs, Social Policy and International Interventions in South East Europe.

49 Chiara Saraceno, ed., Social Assistance Dynamics in Europe: National and Local Poverty Regimes (Bristol: Policy Press, 2002).

50 Gal, "Is There an Extended Family of Mediterranean Welfare States?"

51 Aybars and Tsarouhas, "Straddling Two Continents."

52 Clement Moore Henry and Robert Springborg, Globalization and the Politics of Development in the Middle East (Cambridge, UK and New York: Cambridge University Press, 2010).

53 Nick Manning, "Turkey, the EU and Social Policy," Social Policy and Society 6, no. 4 (2007): 491-501.

54 Deacon and Stubbs, Social Policy and International Interventions in South East Europe.

55 Grütjen, "The Turkish Welfare Regime."

56 World Bank, Turkey: Poverty and Coping after the Crisis. Volume I: Main Report (Washington, DC: World Bank, 2003). 
significant resemblance, though, is the importance of the family as a main institution of welfare. In other respects, however, Turkey did not match the ideal type of a Southern European Model.

Jawad $^{57}$ pointed to the main themes of recent texts concerning Middle Eastern Welfare States: the influence of international intervention; a "statist" political-economic approach to social policy; how state social policy is residual in character, with public policy focused on the "economic" rather than the "social"; clientelism, the politicization of welfare, and the instrumental use of social policy by the state to gain power and political legitimacy; and the influence of Islam on social policy. In the end, however, she concluded that this was only a partial analysis of social policy in the region, presenting a revised history of social policy based on the welfare state as a particular cultural settlement.

$\mathrm{Gal}^{58}$ claimed the existence of an "extended family of Mediterranean welfare states" consisting of eight nations (Cyprus, Greece, Israel, Italy, Malta, Spain, Portugal, and Turkey), which share a number of interesting and crucial commonalities while differing in other ways. For example, this family diverged from the Southern European Model in that it did not have a Bismarckian social protection legacy. He noted that, even though Turkey was clearly an outlier with regard to living standards and social expenditure, observers both within the country and abroad included it in a discussion of the Mediterranean family of nations. ${ }^{59}$

Aybars and Tsarouhas ${ }^{60}$ considered Turkey to be part of the geographic Middle East, sharing historical, political, and cultural traits with other states in the region. Nevertheless, it represented an exceptional case, especially with respect to Europeanization processes in a variety of policies, including social policy. Looking at major trends in social security and labor market arrangements, they argued that Turkey represented a "hybrid" model, one that embodied the characteristics of both Middle Eastern and South European welfare models, yet remained an outlier to both in certain respects.

Gencler and Colak ${ }^{61}$ claimed that Turkey matched the characteristics of the so-called Southern European Model of welfare, ${ }^{62}$ along with Spain, Greece,

57 Rana Jawad, "Review Essay: Possibilities of Positive Social Action in the Middle East: A Re-Reading of the History of Social Policy in the Region," Global Social Policy 8, no. 2 (2008): 267-280; Jawad, Social Welfare and Religion in the Middle East.

58 Gal, "Is There an Extended Family of Mediterranean Welfare States?"

59 Ibid.; Gough, "Social Assistance in Southern Europe”; Grütjen, "The Turkish Welfare Regime."

60 Aybars and Tsarouhas, "Straddling Two Continents."

61 Ayhan Gencler and Aytul Colak, "Globalization, Welfare State and Turkey," 3rd International Symposium on Sustainable Development, May 31-June 1, 2012.

62 Maurizio Ferrera, "The 'Southern Model' of Welfare in Social Europe," Journal of European Social Policy 6, no. 1 (February 1, 1996): 17-37. 
Italy, and Portugal. Their cross-national comparison revealed only a few deviations from this model and noted that "the similarities are remarkable." They went on to state that the most significant common trait of the welfare regimes in Turkey and the rest of Southern Europe was the importance of the family as a main institution of welfare. The existing welfare system in Turkey, they stated, can be considered a minimal and indirect, informal security regime.

Dedeoglu $^{63}$ discussed residual welfare states in the MENA region before turning to feminist typologies of welfare states. She pointed out EspingAndersen's focus on decommodification, which omitted the central role of informal institutions in the provision of welfare in low-income countries. She drew on Moghadam, ${ }^{64}$ who argued that the "developmentalism" of MENA states was undermined by its "neopatriarchal" approach to women, gender, and the family, yet Turkey was somehow different from the other Middle East countries in that, in the mid-1920s, it had placed limitations on the Islamic influence on the organization of the state and headed toward a secular state structure. Women's status in the Turkish welfare system showed a dualistic character of "veiled Europeanisation," one lying between the Middle East and European countries. While there had been a move from the male breadwinner family to a model of universal breadwinner, ${ }^{65}$ there yet remained a "decorative approach to gender issues." She concluded that the Turkish welfare regime is a synthesis of neoliberal and Islamic notions of social solidarity.

Karshenas and Moghadam ${ }^{66}$ and Karshenas et al. ${ }^{67}$ regarded Turkey as part of MENA, a highly gendered "authoritarian corporatist social welfare regime," with female disadvantage continuing to be a hallmark of the MENA region well into the 1990s.

Ultimately, the regional approach is of limited value in classification, as there is little consensus on the nature of the "region." As we have seen, writers have placed Turkey within a wide variety of regions-Arab, Middle Eastern, MENA, South Eastern Europe, Southern Europe, the extended family of Mediterranean nations, and hybrid Mediterranean/MENA-which undermines the possibility of reaching scholarly consensus.

Single-Country Case Studies. The final approach of the studies written in English examines Turkey as a single-country case study. The most significant

63 Dedeoglu, "Veiled Europeanisation of Welfare State in Turkey."

64 Valentine M. Moghadam, "Gender and Social Policy: Family Law and Women's Economic Citizenship in the Middle East," International Review of Public Administration 10, no. 1 (2005): 23-44.

65 Kılıç, "The Gender Dimension of Social Policy Reform in Turkey."

66 Karshenas and Moghadam, "Bringing Social Policy Back in."

67 Karshenas, Moghadam, and Alami, "Social Policy after the Arab Spring." 
tendency here is the classification of Turkey as part of the Southern European welfare regime cluster. Buğra and Keyder co-authored the most cited texts on Turkish social policy, in which they argued that Turkey is part of the Southern European family. In "New Poverty and the Changing Welfare Regime of Turkey," ${ }^{\prime 68}$ they considered Turkey part of the Southern European welfare regime, pointing to a high level of self-employed and unpaid family workers as compared to the low formal employment; informal housing, patronage and clientelistic networks, and traditional and family-based support and solidarity mechanisms; a highly fragmented and hierarchical pension and health insurance system with extreme inequalities based on job status; and a limited role for social assistance for the poor. Buğra and Keyder ${ }^{69}$ and Yakut-Cakar ${ }^{70}$ pointed out how the welfare regime of Turkey resembled the corporatist social security systems of Southern Europe. Kilıç ${ }^{71}$ also noted that Turkey's welfare state policies could especially be likened to those of the so-called Southern European welfare regimes. ${ }^{72}$ Şentürk ${ }^{73}$ argued that in Southern European welfare regimes, which includes Turkey, networks such as family, community, neighborhood, hometown, and political affiliation play a role in sustaining an individual's life during unemployment, sickness, or old age, in addition to regular and formal state interventions and market relations.

Eder $^{74}$ stated that Turkey's welfare state has long been limited and inegalitarian. Strong family ties, coupled with indirect and informal channels of welfare, have compensated for the welfare vacuum. At first glance, Turkey's welfare reform - which emerged from the 2000-2001 crisis-appeared a classic case of moving toward a minimalist, "neoliberal" welfare regime, but there was also evidence of the expansion of state power, with the cumulative effect of a mutated "institutional welfare-mix." The characterization of the welfare regime change in Turkey as a convergence toward a neoliberal paradigm via the retreat of the state, or else as a completely divergent case of new welfare étatism too unique to be compared to other countries, could be highly problematic.

Morvaridi ${ }^{75}$ pointed to "neoliberal welfare governance," where a new form of philanthropy emerged on the back of the neoliberal economic globalization that

68 Buğra and Keyder, "New Poverty and the Changing Welfare Regime of Turkey."

69 Buğra and Keyder, "The Turkish Welfare Regime in Transformation."

70 Yakut-Çakar, "Turkey."

71 Kılıç, "The Gender Dimension of Social Policy Reform in Turkey."

72 Wood and Gough, "A Comparative Welfare Regime Approach to Global Social Policy"; Buğra and Keyder, "The Turkish Welfare Regime in Transformation."

73 Murat Şentürk, "Social Welfare Practices of the State and NGOs in Turkey: New Trends and Necessities," Sosyoloji Dergisi 3, no. 28 (2014): 309-319.

74 Eder, "Retreating State?"

75 Behrooz Morvaridi, "The Politics of Philanthropy and Welfare Governance: The Case of Turkey," The European Journal of Development Research 25, no. 2 (2013): 305-321. 
has encouraged the concentration of wealth in the hands of a few "super-rich" $\underset{m}{z}$ individuals. $\mathrm{He}$ also discussed faith-based philanthropy and Islamic philanthropic organizations, pointing to "a neoliberal model" of the Turkish state and philanthropy, where patronage and clientelism play an important role in welfare distribution.

$\mathrm{Akan}^{76}$ argued that the primary informal social protection mechanism in the Turkish system was the extended family. The existing variables are far from composing a regime of any kind, and therefore it seems more sensible to discuss a social policy structure that has become a "ragtag collection" as a result of the haphazard reform initiatives attempted in response to short-term budgetary and electoral concerns. Buğra and Candas ${ }^{77}$ regarded Turkey as an "eclectic social state" formation best described as a dual citizenship model with a Bismarckian formal social security system that also incorporated informality and clientelism.

$\mathrm{K}_{1}{ }_{1} c^{78}$ discussed the current social policy reform process in Turkey from a gender perspective. The changes undertaken within the scope of the reforms might signal a move from the ideal of the "male-breadwinner family" toward the model of the "universal breadwinner," yet this rough shift from a "genderdifferentiated" toward a "gender-neutral" citizenship did not seem promising for the achievement of equal citizenship for women. Elveren ${ }^{79}$ stated that the welfare regime in Turkey, as a developing country, could be referred to as an "indirect and minimalist welfare regime."

While overall, the Southern European welfare regime thus seems to be the modal conclusion, nevertheless different writers stress different aspects of Turkey's welfare characteristics, and it remains difficult to discover areas of agreement and classification.

\section{Studies written in Turkish}

In contrast to the great diversity of methods and conclusions presented in studies written in the English language, the studies in Turkish lacked original empirical analysis, and they concluded that Turkey was part of the Southern regime.

Rakıci and Yilmaz ${ }^{81}$ argued that Turkey shared the following characteristics common to other members of the Southern regime: fragmented and

76 Taner Akan, "Responsible Pragmatism in Turkish Social Policy Making in the Face of Islamic Egalitarianism and Neoliberal Austerity," International Journal of Social Welfare 20, no. 4 (2011): 367-380.

77 Bugra and Candas, "Change and Continuity under an Eclectic Social Security Regime."

78 Kılıç, "The Gender Dimension of Social Policy Reform in Turkey."

79 Elveren, "Social Security Reform in Turkey."

80 Arın, "The Poverty of Social Security."

81 Cemil Rakıcı and Tarık Zeki Yılmaz, "Refah Devleti Kavramı ve Türkiye'de Refah Devleti Uygulamaları," Finans Politik ve Ekonomik Yorumlar 48, no. 559 (2011): 5-18. 
hierarchical structure due to a large informal economy; premium-based healthcare insurance; social assistance and services decentralized, familycentred, and loosely connected with social insurance system. Taşç1 ${ }^{82}$ focuses on how the elderly were perceived by society at large. He stresses the polarizing and fragmented structure of the regime, which provides "hyper-protection" for formal sector employees an underprotection for others; the exposure of public welfare institutions to partisan and clientelist intervention; the lack of innovation in social assistance programs; and the centrality of religious institutions and the family in welfare provision. He pays particular attention to the tradition of sadaka (Islamic charity) in Turkey, which strengthens the Southern European typology of the country. As in other Southern European countries, welfare provision and the distribution of social risks are based upon the solidarity networks of family, with the state getting involved mainly in a non-systematic manner. Kalayc1 ${ }^{83}$ states that the Turkish welfare system is characterized by the centrality of the family, a fragmented and polarized structure in welfare institutions, and a minimalist and neoliberal nature shown especially by an escalation in privatization. $\mathrm{Kol}^{84}$ focuses on healthcare, pointing out how healthcare care is based on premium payments, rather than on a universalistic principle. She also stresses fragmented and hierarchical social rights; the high degree of discretion, clientelism, and corruption in social policy programs; and the centrality of religion and family in welfare provision. The level of social assistance benefits is low and assistance is granted according to household poverty, thereby strengthening the centrality of family. Dericiler ${ }^{85}$ notes the parallels between Turkey and the Southern European welfare regime cluster: employment dominated by self-employment and petty bourgeoisie or unpaid family labor; wide informality and remittances; social rights unevenly distributed; and a limited state role in welfare provision. Family and religious institutions and local governments play a greater role than the central government in sustaining individuals and coping with risk situations. Toprak ${ }^{86}$ highlights the contrast between the inclusion and high degree of protection for formal state employees, with social assistance and social service provision for

82 Faruk Taşçı, "Refah Devleti Modelleri İçinde Türkiye'nin Pozisyonu:'Yaşlı Algısı' Üzerinden Değerlendirmeler," Insan \& Toplum Dergisi 3, no. 5 (2013): 5-35.

83 İrfan Kalaycı, “iktisadi Kriz Karşısında ‘Sürdürülebilir'Refah Devleti,” SGD Sosyal Güvenlik Dergisi 1, no. 4 (2014): 89-119; İrfan Kalaycı, "Büyük Durgunluk ve Avrupa Refah Devleri Modeli Açısından Norveç, Yunanistan ve Türkiye: Diyalektik iliş̧kiler," Sayıştay Dergisi 90 (2013): 19-47.

84 Emre Kol, "Refah Rejimleri ve Sağlık Hizmetleri," Global Journal of Economics and Business Studies 3, no. 5 (2014): 15-31.

85 Özge Yücel Dericiler, Sosyal Haklar ve Insan Hakları Hukuku Çerçevesinde Devletin Yükümlülükleri: Refah Devletinin Krizi Çerçevesinde Bir Inceleme (Istanbul: On İki Levha Yayınları, 2014).

86 Düriye Toprak, "Uygulamada Ortaya Çıkan Farklı Refah Devleti Modelleri Üzerine Bir İnceleme," Süleyman Demirel Üniversitesi Sosyal Bilimler Enstitüsü Dergisi Yıl 2015/1, no. 21 (2015): 151-175. 
Table 2. Classification and Analysis of Studies on Turkish Welfare Regime (Turkish-Language Studies)

\begin{tabular}{|c|c|c|c|c|c|}
\hline Study & Concepts & Criteria/ Variables & Method & Cluster & \# of Citations \\
\hline Dericiler (2014) & Social rights & Informality and limited state welfare provision & Secondary literature analysis & Southern European & 0 \\
\hline Kalayc1 (2013 and 2014) & Social services & Family solidarity & Secondary literature analysis & Southern European & 0 \\
\hline Kol (2014) & Healthcare & Healthcare expenditures & Secondary literature analysis & Southern European & 0 \\
\hline Rak1c1 and Y1lmaz (2011) & Welfare state applications & $\begin{array}{l}\text { Hierarchical, segmented, and based on family } \\
\text { solidarity and informality }\end{array}$ & Secondary literature analysis & Southern European & 0 \\
\hline Taşçı (2013) & Elderliness & Conception of elderliness & Secondary literature analysis & Southern European & 1 \\
\hline Toprak (2015) & Social expenditure levels & Fragmentation and family & Eyeballing & Southern European & 0 \\
\hline
\end{tabular}


the rest of population, which is highly fragmented, family-centered, and disconnected from the social security system.

\section{Discussion}

Summing up the evidence of all the very diverse studies is problematic. It can be seen that the studies in Turkish all tend to speak with one voice: through discussion of previous work, all seven studies suggest that Turkey is part of the Southern Model. The English-language studies, on the other hand, arrive at a variety of conclusions. Of the 28 studies in English, the modal conclusion from ten studies is "Southern European." In addition, there are some close variations on this, such as the "Latin Rim", the "rudimentary assistance" regime (composed of Southern European nations), and the "extended family of Mediterranean welfare states." However, while all the Turkish- and many of the English-language studies conclude that Turkey is part of the Southern Model, Esping-Andersen ${ }^{87}$ claimed that this was not a distinct grouping, but at most a sub-grouping of the corporatist welfare regime; Manow, ${ }^{88}$ meanwhile, regarded the continental-conservative regime as "ugly" because it is an "undecided regime" that is essentially a residual but diverse category. The next category is that of the "residual welfare state of the MENA region," with three studies. A few studies point to various types of a hybrid or dualistic character. And finally, some of the cluster analyses suggest rather diverse geographical groupings, such as Denmark, Estonia, Norway, Poland, Mexico, and Turkey.

It is also not clear if we should equally weight studies via a simple form of "vote counting," or whether some studies should be weighted more than others. For example, empirical studies could be weighted more than literature reviews or an "eyeballing" of data. Similarly, more stress might perhaps be placed on more highly cited studies, ${ }^{89}$ though it is clear that these studies are not highly cited due to how they classify the Turkish welfare regime. More weight could also be placed on Turkish-language studies, or English-language studies by Turkish scholars, since the authors are more familiar with the nation, but these tend to be less cited.

Some of these diverse conclusions can be explained by the different approaches adopted. Unsurprisingly, for example, regional approaches tend to find regional clusters (although different regions, such as Southern European

87 Esping-Andersen, Social Foundations of Postindustrial Economies.

88 Philip Manow, “'The Good, the Bad, and the Ugly': Esping-Andersen's Regime Typology and the Religious Roots of the Western Welfare State," MPIfG Working Paper 04/3 (Cologne: Max Planck Institute for the Study of Societies, 2004).

89 Henry and Springborg, Globalization and the Politics of Development in the Middle East; Gough et al., "Social Assistance in OECD Countries." 
or MENA, are put forward), while cluster analyses tend to find clusters that are not geographically contiguous, such as "successful informal security regimes." However, the studies may also be associated with different criteria and variables. It is noticeable that few of the studies draw on the Esping-Andersen criteria of decommodification, stratification, welfare mix, or defamilialization. In some cases, studies justify their approach, often modifying Esping-Andersen, but in other cases variables (sometimes expenditure variables, which were rejected by Esping-Andersen) are produced with little justification. Some of the studies appear rather descriptive, and require better concepts and measures. For example, Eder ${ }^{90}$ focuses on the welfare mix, but with no direct reference to Esping-Andersen. ${ }^{91}$ Some of the feminist studies do not discuss defamilialization. ${ }^{92}$ Manow $^{93}$ points to the neglected role of religion in Esping-Andersen's three worlds. Similarly, it has been argued that there is a need to reconstitute future social policy in the region by taking better account of how religious values and ideals influence social welfare. ${ }^{94}$

Moreover, some of the earlier conclusions reached may no longer hold. First, Gough ${ }^{95}$ overturned his earlier view ${ }^{96}$ that there is a distinctive Southern European assistance regime, although the earlier conclusion is still cited by other writers. Second, a number of writers have argued that the Turkish welfare regime has undergone a major transformation since the mid-1990s. ${ }^{97}$ However, it is not certain exactly what this "regime" is, ${ }^{98}$ and while Özkan ${ }^{99}$ discusses welfare regime change, it is not entirely clear where the regime is moving from or to. Although no scholar classified Turkey as a "liberal welfare regime", several of them noted neoliberal influences, which may suggest the

90 Eder, "Retreating State?"

91 See also Martin Powell and Armando Barrientos, "Welfare Regimes and the Welfare Mix," European Journal of Political Research 43, no. 1 (January 1, 2004): 83-105.

92 Esping-Andersen, Social Foundations of Postindustrial Economies; Henning Lohmann and Hannah Zagel, "Family Policy in Comparative Perspective: The Concepts and Measurement of Familization and Defamilization," Journal of European Social Policy 26, no. 1 (2016): 48-65.

93 Manow, "The Good, the Bad, and the Ugly."

94 Jawad, "Review Essay"; Jawad, Social Welfare and Religion in the Middle East; Rana Jawad and Burcu Yakut-Cakar, "Religion and Social Policy in the Middle East: The (Re) Constitution of an Old-New Partnership," Social Policy \& Administration 44, no. 6 (2010): 658-672.

95 Gough, "Social Assistance Regimes."

96 Gough, "Social Assistance in Southern Europe."

97 Buğra and Keyder, "The Turkish Welfare Regime in Transformation"; Ağartan, "Turkish Health System in Transition"; Kılıç, "The Gender Dimension of Social Policy Reform in Turkey”; Umut Özkan, "The Translation of Competing Ideas to the Turkish Welfare-Production Regime," in Annual Conference of the International Sociological Association's (ISA) Research Committee on Poverty, Social Welfare and Social Policy (RC19), Montreal, Quebec, 2009, http://www.cccg.umontreal.ca/RC19/PDF/OzkanU_Rc192009.pdf; Aybars and Tsarouhas, "Straddling Two Continents."

98 Akan, "Responsible Pragmatism."

99 Özkan, "The Translation of Competing Ideas." 
possibility of "regime change" in the future. For example, in the 1980s, in parallel to the overall neoliberal paradigm in the world, the regime started to change toward a market-oriented structure. ${ }^{100} \mathrm{Akan}^{101}$ discusses the sociopolitical context of Turkish social policy in neoliberal times. Gencler and Colak ${ }^{102}$ state that the social security system of Turkey has been restructured, particularly since the early 1990s, in line with the neoliberal paradigm. Morvaridi ${ }^{103}$ points to "neoliberal welfare governance." A number of writers point to the neoliberal influence of external agencies such as the World Bank and IMF ${ }^{104}$ However, Eder ${ }^{105}$ claims that the picture is more complex than neoliberalism, while Özbudun ${ }^{106}$ points to the growing trend towards conservatism, noting especially the AKP's shift towards conservatism and authoritarianism.

\section{Conclusion}

In this article, we have conducted a meta-analysis of studies that classify Turkey within existing welfare regime families. We have brought together all the studies that have this objective in mind and drawn conclusions about the main trends in the literature based on the meta-analysis. It appears that studies classifying the Turkish welfare regime exhibit a significant degree of variation in terms of both their approaches and their conclusions, which results in little in the way of consensus and a notable degree of difficulty in differentiating between a large and confusing range of alternative terms. There are important differences between the views of different groups of scholars. Some of these differences may reflect familiarity with the country; that is, a deep knowledge of Turkey as compared to an observation made within statistical modeling. However, there are also different views on classification: while the majority view is that Turkey is part of the "Southern Model," other accounts suggest that it is part of a wide variety of other "regions." Whereas the studies in Turkish tend to agree that Turkey is part of the Southern Model, the English-language studies arrive at a variety of conclusions, though their

\footnotetext{
100 Elveren, "Social Security Reform in Turkey"; Adem Y. Elveren, "Assessing Gender Inequality in the Turkish Pension System," International Social Security Review 61, no. 2 (2008): 39-58.

101 Akan, "Responsible Pragmatism."

102 Gencler and Colak, "Globalization, Welfare State and Turkey."

103 Morvaridi, "The Politics of Philanthropy and Welfare Governance."

104 Elveren, "Social Security Reform in Turkey"; Deacon and Stubbs, Social Policy and International Interventions in South East Europe; Kilıç, "The Gender Dimension of Social Policy Reform in Turkey"; Akan, "Responsible Pragmatism."

105 Eder, "Retreating State?"

106 Ergun Özbudun, "AKP at the Crossroads: Erdoğan's Majoritarian Drift," South European Society and Politics 19, no. 2 (2014): 155-167.
} 
overall modal conclusion is for the "Southern European" model. This, however, goes against the view of Esping-Andersen, ${ }^{107}$ who denies that such a model exists. In his view, this is not a distinct cluster but, at most, a sub-grouping of the corporatist welfare regime. Moreover, other "regional" studies conclude that Turkey is part of the MENA region, while many of the cluster analyses suggest a wide variety of clusters that are not geographically contiguous. In short, despite the extensive literature on the "worlds" of welfare capitalism, this study has shown that application to one country is problematic in that there is little consensus regarding approach, method, concepts, data, and conclusions. Finally, the studies reviewed are necessarily dated, having been written at a range of dates in the past. They all tend to focus on static classifications made at one particular point in time. However, as noted above, it can be argued that the Turkish welfare regime is rapidly changing. In particular, it may be transforming into part of a welfare regime family of emerging market economies, and it is unclear if the tools of the Esping-Andersen approach are suitable for a country such as Turkey. This may suggest a potentially fruitful research agenda for future scholars of the welfare regimes in Turkey.

\section{References}

Abu Sharkh, Miriam and lan Gough. "Global Welfare Regimes: A Cluster Analysis." Global Social Policy 10, no. 1 (April 1, 2010): 27-58. doi:10.1177/1468018109355035.

Agartan, Tuba Inci. Turkish Health System in Transition: Historical Background and Reform Experience. ProQuest, 2008.

"Aile ve Sosyal Politikalar Bakanlığının 2015 yılı bütçesinin görüşmeleri TBMM Plan ve Bütçe Komisyonu'nda tamamlandı." November 6, 2014. http://www.aile.gov.tr/haberler/aile-vesosyal-politikalar-bakanliginin-2015-yili-butcesinin-gorusmeleri-tbmm-plan-ve-butce-komisyonundatamamlandi.

Akan, Taner. "Responsible Pragmatism in Turkish Social Policy Making in the Face of Islamic Egalitarianism and Neoliberal Austerity." International Journal of Social Welfare 20, no. 4 (2011): 367-380.

Arın, Tülay. "The Poverty of Social Security: The Welfare Regime in Turkey." In The Ravages of Neoliberalism: Society and Gender in Turkey. Edited by Neşecan Balkan and Sungur Savran. New York: Nova Science Publishers, 2002. 73-91.

Aybars, Ayse Idil and Dimitris Tsarouhas. "Straddling Two Continents: Social Policy and Welfare Politics in Turkey." Social Policy \& Administration 44, no. 6 (2010): 746-763.

Aysan, Mehmet Fatih. "Reforms and Challenges: The Turkish Pension Regime Revisited." Emerging Markets Finance and Trade 49, no. sup5 (2013): 148-162.

Bugra, Ayşe and Aysen Candas. "Change and Continuity under an Eclectic Social Security Regime: The Case of Turkey." Middle Eastern Studies 47, no. 3 (2011): 515-528.

Buğra, Ayşe and Çağlar Keyder. New Poverty and the Changing Welfare Regime of Turkey. Ankara: UNDP, 2003.

"The Turkish Welfare Regime in Transformation." Journal of European Social Policy 16, no. 3 (August 1, 2006): 211-228. doi:10.1177/0958928706065593.

107 Esping-Andersen, Social Foundations of Postindustrial Economies. 
Deacon, Bob and Paul Stubbs, eds. Social Policy and International Interventions in South East Europe. Cheltenham, UK and Northampton, MA: Edward Elgar Publishing, 2007.

Dedeoglu, Saniye. "Veiled Europeanisation of Welfare State in Turkey: Gender and Social Policy in the 2000s." Women's Studies International Forum 41, no. 1 (2013): 7-13. doi:10.1016/ j.wsif.2013.03.009.

Eardley, Tony, Jonathan Bradshaw, John Ditch, lan Gough, and Peter Whiteford. Social Assistance in OECD Countries. London: HM Stationery Office, 1996. https://www.york.ac.uk/inst/spru/pubs/pdf/ rrep046.pdf.

Eder, Mine. "Retreating State? Political Economy of Welfare Regime Change in Turkey." Middle East Law and Governance 2, no. 2 (2010): 152-184.

Elveren, Adem Y. "Assessing Gender Inequality in the Turkish Pension System." International Social Security Review 61, no. 2 (2008): 39-58.

. "Social Security Reform in Turkey: A Critical Perspective." Review of Radical Political Economics 40, no. 2 (June 1, 2008): 212-232. doi:10.1177/0486613407310561.

Esping-Andersen, Gosta. The Three Worlds of Welfare Capitalism. Princeton, NJ: Princeton University Press, 1990.

Social Foundations of Postindustrial Economies. Oxford: Oxford University Press, 1999.

Ferrera, Maurizio. "The 'Southern Model' of Welfare in Social Europe." Journal of European Social Policy 6, no. 1 (February 1, 1996): 17-37. doi:10.1177/095892879600600102.

Gal, John. "Is There an Extended Family of Mediterranean Welfare States?" Journal of European Social Policy 20, no. 4 (2010): 283-300.

Gencler, Ayhan and Aytul Colak, "Globalization, Welfare State and Turkey." 3rd International Symposium on Sustainable Development, May 31-June 1, 2012.

Gough, lan. "East Asia: The Limits of Productivist Regimes." In Insecurity and Welfare Regimes in Asia, Africa, and Latin America: Social Policy in Development Contexts. Edited by Geoffrey D Wood, Armando Barrientos, Philippa Bevan, Peter Davis, Graham Room, and lan Gough. Cambridge: Cambridge University Press, 2004. 169-201.

. "European Welfare States: Explanations and Lessons for Developing Countries." In Inclusive States: Social Policy and Structural Inequalities. Edited by Anis Ahmad Dani and Harjan de Haan. Washington, DC: World Bank Publications, 2008. 39-72.

. "Social Assistance in Southern Europe." South European Society \& Politics 1, no. 1 (1996): 1-23.

. "Social Assistance Regimes: A Cluster Analysis." Journal of European Social Policy 11, no. 2 (May 1, 2001): 165-170. doi:10.1177/095892870101100205.

Gough, lan and Miriam Abu Sharkh. "Financing Welfare Regimes: Mapping Heterogeneous Revenue Structures." International Journal of Social Welfare 20, no. 3 (2011): 280-291.

Gough, lan, Jonathan Bradshaw, John Ditch, Tony Eardley, and Peter Whiteford. "Social Assistance in OECD Countries." Journal of European Social Policy 7, no. 1 (February 1, 1997): 17-43. doi:10.1177/095892879700700102.

Gough, lan and Göran Therborn. "The Global Future of Welfare States." In The Oxford Handbook of the Welfare State. Edited by Francis G. Castles, Stephan Leibfried, Jane Lewis, Herbert Obinger, and Christopher Pierson. Oxford: Oxford University Press, 2010. 741-758. http://personal.Ise.ac.uk/ goughi/Gough\%20Therborn\%20final_chapter_47_17.09.2009_10.46.31.pdf.

Gough, lan, Geoffrey D. Wood, Armando Barrientos, Philippa Bevan, Peter Davis, and Graham Room, eds. Insecurity and Welfare Regimes in Asia, Africa, and Latin America: Social Policy in Development Contexts. Cambridge, UK and New York: Cambridge University Press, 2004.

Grütjen, Daniel. "The Turkish Welfare Regime: An Example of the Southern European Model? The Role of the State, Market and Family in Welfare Provision." Turkish Policy Quarterly 7, no. 1 (2008): 111-129.

Henry, Clement Moore and Robert Springborg. Globalization and the Politics of Development in the Middle East. Cambridge, UK and New York: Cambridge University Press, 2010.

Hudson, John and Stefan Kühner. "Analyzing the Productive and Protective Dimensions of Welfare: Looking Beyond the OECD." Social Policy \& Administration 46, no. 1 (February 1, 2012): 35-60. doi:10.1111/j.1467-9515.2011.00813.x. 
International Labour Organization (ILO). World Social Protection Report: Building Economic Recovery, Inclusive Development and Social Justice, 2014-15. Geneva: International Labour Office, 2015. http://www.ilo.org/wcmsp5/groups/public/_dgreports/—dcomm/documents/publication/wcms_ 245201.pdf.

Jawad, Rana. "Review Essay: Possibilities of Positive Social Action in the Middle East: A Re-Reading of the History of Social Policy in the Region." Global Social Policy 8, no. 2 (2008): 267-280.

Social Welfare and Religion in the Middle East: A Lebanese Perspective. Bristol: Policy Press, 2009.

Jawad, Rana and Burcu Yakut-Cakar. "Religion and Social Policy in the Middle East: The (Re) Constitution of an Old-New Partnership." Social Policy \& Administration 44, no. 6 (2010): 658-672.

Kalaycı, İrfan. "Büyük Durgunluk ve Avrupa Refah Devleri Modeli Açısından Norveç, Yunanistan ve Türkiye: Diyalektik Ilişkiler." Sayıştay Dergisi 90 (2013): 19-47. https://www.sayistay.gov.tr/tr/Upload/ 95906369/files/dergi/pdf/der90m2.pdf.

. “iktisadi Kriz Karşısında ‘Sürdürülebilir'Refah Devleti.” SGD Sosyal Güvenlik Dergisi 1, no. 4 (2014): 89-119.

Karshenas, Massoud and Valentine M. Moghadam. "Bringing Social Policy Back in: A Look at the Middle East and North Africa." International Journal of Social Welfare 18, no. s1 (2009): 52-61.

—. "Social Policy in the Middle East: Introduction and Overview." In Social Policy in the Middle East: Economic, Political and Gender Dynamics. Edited by Massoud Karshenas and Valentine M. Moghadam. Basingstoke: Palgrave Macmillan, 2006. 1-30.

Karshenas, Massoud, Valentine M. Moghadam, and Randa Alami. "Social Policy after the Arab Spring: States and Social Rights in the MENA Region." World Development 64 (2014): 726-739.

Kılıç, Azer. "The Gender Dimension of Social Policy Reform in Turkey: Towards Equal Citizenship?" Social Policy \& Administration 42, no. 5 (2008): 487-503.

Kol, Emre. "Refah Rejimleri ve Sağlık Hizmetleri." Global Journal of Economics and Business Studies 3, no. 5 (2014): 15-31.

Lohmann, Henning and Hannah Zagel. "Family Policy in Comparative Perspective: The Concepts and Measurement of Familization and Defamilization." Journal of European Social Policy 26, no. 1 (2016): 48-65.

Manning, Nick. "Turkey, the EU and Social Policy." Social Policy and Society 6, no. 4 (2007): 491-501.

Manow, Philip. "The Good, the Bad, and the Ugly': Esping-Andersen's Regime Typology and the Religious Roots of the Western Welfare State.” MPIfG Working Paper 04/3. Cologne: Max Planck Institute for the Study of Societies, 2004. http://www.ssoar.info/ssoar/handle/document/36437.

Moghadam, Valentine M. "Gender and Social Policy: Family Law and Women's Economic Citizenship in the Middle East." International Review of Public Administration 10, no. 1 (2005): 23-44.

- Modernizing Women: Gender and Social Change in the Middle East. Boulder: Lynne Rienner Publishers, 2003.

. "The Political Economy of Female Employment in the Arab Region." In Gender and Development in the Arab World: Women's Economic Participation, Patterns and Policies. Edited by Nabil F. Khoury and Valentine M. Moghadam. London: Zed Books, 1995. 6-34.

-Women, Work, and Economic Reform in the Middle East and North Africa. Boulder: Lynne Rienner, 1998.

Morvaridi, Behrooz. "The Politics of Philanthropy and Welfare Governance: The Case of Turkey." The European Journal of Development Research 25, no. 2 (2013): 305-321.

Organisation for Economic Co-operation and Development (OECD). "Social Expenditure - Aggregated Data." 2012. http://stats.oecd.org/Index.aspx?datasetcode=SOCX_AGG.

Özbudun, Ergun. "AKP at the Crossroads: Erdoğan's Majoritarian Drift." South European Society and Politics 19, no. 2 (2014): 155-167.

Özgür, Bahadır. “işte Ak Parti'nin 'Sosyal Yardım' Gerçeği!” Radikal. December 29, 2014. http://www. radikal.com.tr/politika/iste-ak-partinin-sosyal-yardim-gercegi-1260849/.

Özkan, Umut. "The Translation of Competing Ideas to the Turkish Welfare-Production Regime." In Annual Conference of the International Sociological Association's (ISA) Research Committee on Poverty, Social Welfare and Social Policy (RC19), Montreal, Quebec. 2009. http://www.cccg.umontreal.ca/RC19/ PDF/Ozkan-U_Rc192009.pdf. 
Piven, Frances Fox and Lorraine C. Minnite. "Crisis, Convulsion and the Welfare State." In Social Policy in Times of Austerity: Towards a New International Political Economy of Welfare. Edited by Kevin Farnsworth and Zoe Irving. Bristol: Policy Press, 2015. 143-170.

$z$ _. "Poor People's Politics." In The Oxford Handbook of the Social Science of Poverty. Edited by David Brady and Linda M. Burton. Oxford: Oxford University Press, 2016. 751-773.

Powell, Martin and Armando Barrientos. "Welfare Regimes and the Welfare Mix." European Journal of Political Research 43, no. 1 (January 1, 2004): 83-105. doi:10.1111/j.1475-6765.2004.00146.x.

Rakıcı, Cemil and Tarık Zeki Yılmaz. "Refah Devleti Kavramı ve Türkiye'de Refah Devleti Uygulamaları." Finans Politik ve Ekonomik Yorumlar 48, no. 559 (2011): 5-18.

Rudra, Nita. "Welfare States in Developing Countries: Unique or Universal?" Journal of Politics 69, no. 2 (May 1, 2007): 378-396. doi:10.1111/j.1468-2508.2007.00538.x.

Saraceno, Chiara, ed. Social Assistance Dynamics in Europe: National and Local Poverty Regimes. Bristol: Policy Press, 2002.

Seekings, Jeremy. "Prospects for Basic Income in Developing Countries: A Comparative Analysis of Welfare Regimes in the South." University of Cape Town, 2005. http://open.uct.ac.za/handle/ 11427/19413.

Şentürk, Murat. "Social Welfare Practices of the State and NGOs in Turkey: New Trends and Necessities." Sosyoloji Dergisi 3, no. 28 (2014): 309-319.

Taşçı, Faruk. "Refah Devleti Modelleri İçinde Türkiye'nin Pozisyonu:'Yaşlı Algısı' Üzerinden Değerlendirmeler." Insan \& Toplum Dergisi 3, no. 5 (2013): 5-35.

Toprak, Düriye. "Uygulamada Ortaya Çıkan Farklı Refah Devleti Modelleri Üzerine Bir İnceleme." Süleyman Demirel Üniversitesi Sosyal Bilimler Enstitüsü Dergisi Yıl 2015/1, no. 21 (2015): 151-175. http://sbedergi.sdu.edu.tr/assets/uploads/sites/343/files/07-21-15072015.pdf.

Üçkardeşler, Emre. “Turkey's Changing Social Policy Landscape.” Turkish Policy Quarterly 13, no. 4 (2015): 149-161.

Wood, Geof and lan Gough. "A Comparative Welfare Regime Approach to Global Social Policy." World Development 34, no. 10 (2006): 1696-1712. doi:10.1016/j.worlddev.2006.02.001.

World Bank. Turkey: Poverty and Coping after the Crisis. Volume I: Main Report. Washington, DC: World Bank, 2003. http://documents.worldbank.org/curated/en/824491468778225121/pdf/24185 OTROSR.pdf.

The State of Social Safety Nets 2015. Washington, DC: World Bank, 2015. http://documents. worldbank.org/curated/en/415491467994645020/pdf/97882-PUB-REVISED-Box393232B-PUBLIC-DOC DATE-6-29-2015-DOI-10-1596978-1-4648-0543-1-EPI-1464805431.pdf.

Yakut-Cakar, Burcu. "Turkey." In Social Policy and International Interventions in South East Europe. Edited by Bob Deacon and Paul Stubbs. Cheltenham, UK and Northampton, MA: Edward Elgar Publishing, 2007. 103-129.

Yoltar, Çağri. "When the Poor Need Health Care: Ethnography of State and Citizenship in Turkey." Middle Eastern Studies 45, no. 5 (September 1, 2009): 769-782. doi:10.1080/00263200903135562.

Yörük, Erdem. "Welfare Provision as Political Containment: The Politics of Social Assistance and the Kurdish Conflict in Turkey." Politics \& Society 40, no. 4 (December 1, 2012): 517-547. doi:10.1177/0032329212461130.

Yücel, Dericiler. Özge. Sosyal Haklar ve Insan Hakları Hukuku Çerçevesinde Devletin Yükümlülükleri: Refah Devletinin Krizi Çerçevesinde Bir Inceleme. Istanbul: On İki Levha Yayınları, 2014. 